\title{
Validation of the Tracmor triaxial accelerometer system for walking
}

Citation for published version (APA):

Levine, J., Baukol, P. A., \& Westerterp, K. R. (2001). Validation of the Tracmor triaxial accelerometer system for walking. Medicine and Science in Sports and Exercise, 33, 1593-1597.

https://doi.org/10.1097/00005768-200109000-00024

Document status and date:

Published: 01/01/2001

DOI:

10.1097/00005768-200109000-00024

Document Version:

Publisher's PDF, also known as Version of record

Document license:

Taverne

Please check the document version of this publication:

- A submitted manuscript is the version of the article upon submission and before peer-review. There can be important differences between the submitted version and the official published version of record.

People interested in the research are advised to contact the author for the final version of the publication, or visit the DOI to the publisher's website.

- The final author version and the galley proof are versions of the publication after peer review.

- The final published version features the final layout of the paper including the volume, issue and page numbers.

Link to publication

\footnotetext{
General rights rights.

- You may freely distribute the URL identifying the publication in the public portal. please follow below link for the End User Agreement:

www.umlib.nl/taverne-license

Take down policy

If you believe that this document breaches copyright please contact us at:

repository@maastrichtuniversity.nl

providing details and we will investigate your claim.
}

Copyright and moral rights for the publications made accessible in the public portal are retained by the authors and/or other copyright owners and it is a condition of accessing publications that users recognise and abide by the legal requirements associated with these

- Users may download and print one copy of any publication from the public portal for the purpose of private study or research.

- You may not further distribute the material or use it for any profit-making activity or commercial gain

If the publication is distributed under the terms of Article $25 \mathrm{fa}$ of the Dutch Copyright Act, indicated by the "Taverne" license above, 


\title{
Validation of the Tracmor triaxial accelerometer system for walking
}

\author{
J. A. LEVINE, P. A. BAUKOL, and K. R. WESTERTERP \\ Endocrine Research Unit, Mayo Clinic, Rochester, MN 55905, and Department of Human Biology, University of \\ Maastricht, Maastricht, THE NETHERLANDS
}

\begin{abstract}
LEVINE, J. A., P. A. BAUKOL, and K. R. WESTERTERP. Validation of the Tracmor triaxial accelerometer system for walking. Med. Sci. Sports Exerc., Vol. 33, No. 9, 2001, pp. 1593-1597. Purpose: Walking is likely to contribute substantially to nonexercise activity thermogenesis. The Tracmor triaxial accelerometer system (Maastricht, The Netherlands) is the most widely validated system for detecting body movement in free-living subjects. The aim of this study was to validate the Tracmor triaxial accelerometer system for estimating the energy expenditure of walking. Methods: Experiments were conducted in healthy subjects. First, baseline variability for Tracmor output was determined for subjects standing still. Second, Tracmor output was compared for walking on a treadmill and on level ground. Third, both Tracmor output and energy expenditure were compared for walking on a treadmill and walking on level ground. Finally, the effect of gradient on Tracmor output and energy expenditure was compared for subjects walking on a treadmill. Results: The data demonstrated excellent reproducibility for comparing Tracmor output for standing $(\mathrm{CV}<2 \%)$. There were excellent log-linear relationships between velocity and Tracmor output walking on a treadmill $(r=0.998)$ and on level ground $(r=0.999)$. Tracmor output and the energy expenditure of walking were inseparable for the two modalities of walking. However, the variance in response was such that to reliably derive the relationship between Tracmor output and energy expenditure, separate regression equations are needed for each subject. Finally, the Tracmor accelerometer did not detect the increased energy expenditure of walking that occurs as gradient increases. Conclusion: The Tracmor triaxial accelerometer provides reproducible and reliable data on the body motion associated with walking regardless of whether a subject walks on a treadmill or level ground. Tracmor units can be used to predict the energetic cost of walking provided that separate regression equations are derived for each subject to convert Tracmor output to energy expenditure. Key Words: ENERGY EXPENDITURE, MOVEMENT REGISTRATION, PHYSICAL ACTIVITY
\end{abstract}

$\mathrm{W}$ alking, even at slow pace, results in doubling of energy expenditure, and because free-living individuals ambulate throughout the day, walking is likely to represent a major component of nonexercise activity thermogenesis (10). One of the most precise, reproducible, and extensively validated tools for quantifying walking in free-living individuals is the Tracmor triaxial accelerometer (Maastricht, The Netherlands) $(2,3,5,6,13)$. Validation experiments on walking for the Tracmor units (TU) have been limited to treadmills, even though the mechanics of walking on a treadmill differ from those used in walking on level ground $(11,14)$ because there is no forward displacement of the body. Also, the ability of the TU to detect the metabolic cost of walking at different inclinations has not been evaluated. We designed experiments to establish the utility and limitations of the TU for quantifying the metabolic cost of walking.

We tested four hypotheses. The first hypothesis was that baseline Tracmor output is reproducible for individuals standing stationary. The second hypothesis was that Tracmor output is similar for walking on a treadmill and on level ground. The third hypothesis was that the energy expendi-

0195-9131/01/3309-1593/\$3.00/0

MEDICINE \& SCIENCE IN SPORTS \& EXERCISE ${ }_{\circledast}$

Copyright (C) 2001 by the American College of Sports Medicine

Submitted for publication October 2000.

Accepted for publication November 2000. ture of walking and Tracmor output are similar for walking on a treadmill and on level ground. The fourth hypothesis was that the effect of inclination on the energy expenditure of walking would be reflected by concordant changes in Tracmor output.

\section{METHODS}

\section{Subjects}

All subjects were healthy, used no medications, did not abuse alcohol or drugs, and did not smoke. Subjects were excluded if they exercised more than four times per week or if they had a physically strenuous occupation. Subjects provided written informed consent.

\section{Tracmor Accelerometer}

The Tracmor triaxial accelerometer unit (Fig. 1) comprises three uniaxial piezoresistive accelerometers (ICSensors 3031-010, Druck Nederland, The Netherlands) mounted orthogonally in a resin block $(50 \times 30 \times 8 \mathrm{~mm}$, $16 \mathrm{~g}$ ) whereby each axis is independently sensed (2). The accelerometer was attached to the subject's lower back using a $70 \times 85$-mm piece of adhesive plastic (Tegaderm, $3 \mathrm{M}$, Minneapolis, MN). A cable connected the accelerometer to a portable data logger (Tattletale 5F, Onset Computer, $512 \mathrm{kB}, 16$-bit, $10 \times 70 \times 35 \mathrm{~mm}, 250 \mathrm{~g}$; Bourne, MA). Data for each axis were amplified and filtered (0.11 


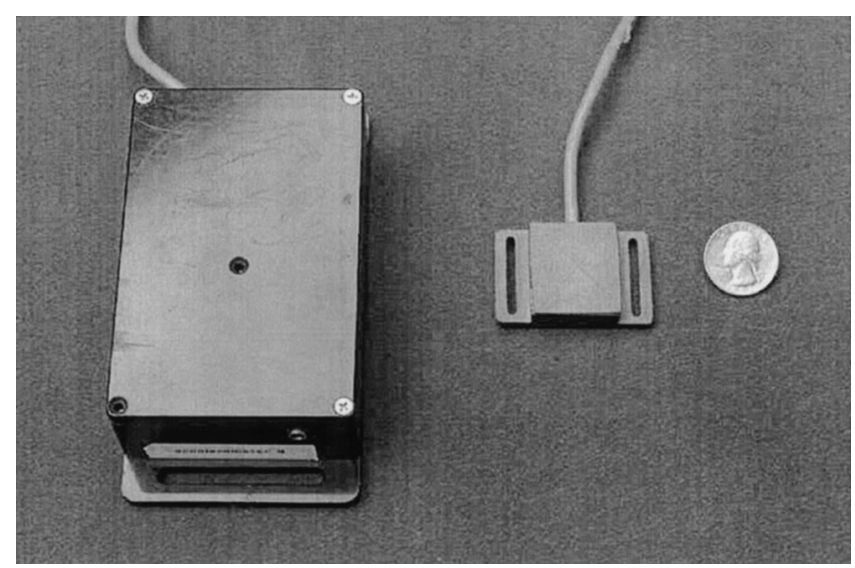

FIGURE 1-The Tracmor accelerometer: the data logger (left) is connected by a cable to the accelerometer unit (right) that is attached to the subject's back.

Hz high pass, $20 \mathrm{~Hz}$ low pass) to attenuate the DC responses and the sum of the rectified and integrated acceleration curves for the three axes measured. Data were recorded continuously and downloaded to a computer after each experiment.

\section{Energy Expenditure}

Energy expenditure was measured using a flow-over, indirect calorimeter $\left(\mathrm{V}_{\max } 29 \mathrm{~N}\right.$, SensorMedics, Yorba Linda, CA) and face mask system. Expired air was collected using a full-face transparent mask (Scott Aviation, Lancaster, NY). The face mask was connected to the calorimeter by $15 \mathrm{~m}$ of 22-mm-diameter leakproof tubing (Hans Rudolph Inc, Kansas, MO). Before each measurement, the calorimeter was calibrated for flow using a 3-L calibrated syringe and for gas concentrations using two primary standard span gases $\left(4 \% \mathrm{CO}_{2}, 16 \% \mathrm{O}_{2}\right.$, and $26 \% \mathrm{O}_{2}$; balance $\mathrm{N}_{2}$ ). Gas flow through the system was modulated to maintain $\mathrm{O}_{2}$ and $\mathrm{CO}_{2}$ concentrations within the optimum range for the sensors and physiological comfort. Data were integrated every $30 \mathrm{~s}$ and stored in a computer. The precision of the calorimeter was tested monthly by burning measured masses of high-purity ethanol (AAPER Alcohol and Chemical Company, Shelbyville, KN) within the system using a specialized apparatus (SensorMedics). The response time of the calorimeter at a flow rate of $30 \mathrm{~L} \cdot \mathrm{min}^{-1}$ was $\sim 30 \mathrm{~s}$.

Experiment 1: Baseline TU stability while standing stationary. Before investigating the effect of walking on Tracmor output, we first needed to document the variability in Tracmor output (measured in TU) while subjects stood immobile. To address this issue, a TU was attached to 11 nonobese subjects who stood motionless for $20 \mathrm{~min}$. The subjects were six women and five men. Their mean $( \pm \mathrm{SD})$ age was $33 \pm 5 \mathrm{yr}$, and their mean weight was $66 \pm 9 \mathrm{~kg}$ (body mass index (BMI), $23 \pm 3 \mathrm{~kg} / \mathrm{m}^{2}$ ). Each subject was studied on a separate day.

Experiment 2: Comparison of TU output walking on a treadmill and walking on flat ground. We speculated that because the mechanics of walking on a treadmill and on level ground are inherently different (stationary body position compared with linear body velocity) $(11,14)$, Tracmor output might differ between these modalities of walking. We therefore compared Tracmor output for walking on a treadmill with walking on level ground. Our eight healthy subjects were four women and four men with a mean age of $33 \pm 9 \mathrm{yr}$, mean weight of $78 \pm 20 \mathrm{~kg}$, and mean BMI of $25 \pm 3 \mathrm{~kg} / \mathrm{m}^{2}$. They were studied $>4 \mathrm{~h}$ after eating, in the morning, while lightly clothed and wearing rubber-soled tennis shoes. The TU was attached, and subjects were randomly assigned to perform either the treadmill component or the level ground component of the study first. Subjects rested for $60 \mathrm{~min}$ between components. For the treadmill component, subjects stood motionless on the treadmill $(0$ $\mathrm{m} \cdot \mathrm{min}^{-1}$ ) for $10 \mathrm{~min}$ and then walked at 32,62 , and 86 $\mathrm{m} \cdot \mathrm{min}^{-1}$, each for $10 \mathrm{~min}$. The treadmill used in these experiments (Q3000, Quinton, Seattle, WA) was independently validated for velocity. For the level ground component, subjects initially stood motionless $\left(0 \mathrm{~m} \cdot \mathrm{min}^{-1}\right)$ in a 200 - $\mathrm{ft}$ level corridor for $10 \mathrm{~min}$ and then walked at 32,62 , and $86 \mathrm{~m} \cdot \mathrm{min}^{-1}$, each for $10 \mathrm{~min}$. To ensure the exact and correct velocity, an investigator paced the subjects by walking alongside them throughout this component.

Experiment 3: The energy expenditure of walking compared between walking on a treadmill and walking on level ground. Even if Tracmor output was similar for walking on a treadmill or level ground, we speculated that the energy expenditure of walking on a treadmill and on level ground might be different. When walking on a treadmill, the body does not move forward in space, whereas when walking on level ground, body mass moves forward. We therefore measured the energy expenditure while walking on the treadmill and on level ground. The seven weight-stable (no fluctuation in body weight $>2$ $\mathrm{kg}$ in the 3 months before study), rested subjects were six women and one man with a mean age of $33 \pm 11 \mathrm{yr}$, mean weight of $74 \pm 16 \mathrm{~kg}$, and mean BMI of $26 \pm 3 \mathrm{~kg} / \mathrm{m}^{2}$. They were studied in the morning after having fasted from $2200 \mathrm{~h}$ the night before. Tracmor output and energy expenditure were measured concurrently while subjects walked on the treadmill and on level ground. The treadmill and level ground components were randomized with a 60 -min rest period between components. For each component, subjects were measured while standing motionless for $20 \mathrm{~min}$ and then while walking at 32,62 , and $86 \mathrm{~m} \cdot \mathrm{min}^{-1}$ for $14 \mathrm{~min}$ each. While the subjects were walking on level ground, the same indirect calorimeter system described above was used. The calorimeter remained stationary throughout the measurement, and the investigator carried the extended hosing behind the subject. The same hosing was used for both components of the protocol.

Experiment 4: The effect of inclination on the energy expenditure of walking and Tracmor output. In free-living subjects, walking generally occurs on level ground (i.e., in buildings). However, terrain varies outdoors, and as the incline becomes steeper, the metabolic cost of walking increases. Does Tracmor output, for a given velocity, increase with increasing inclination to match the increase in energy expenditure? To ascertain whether the 
TABLE 1. Log TU for velocities while walking on a treadmill and level ground.

\begin{tabular}{|c|c|c|c|c|c|c|c|c|c|c|c|}
\hline & \multirow{2}{*}{$\begin{array}{r}\text { Velocity } \\
\left(\mathrm{m} \cdot \mathrm{min}^{-1}\right)\end{array}$} & \multicolumn{8}{|c|}{ Subject } & \multirow[b]{2}{*}{ Mean } & \multirow[b]{2}{*}{ SD } \\
\hline & & 1 & 2 & 3 & 4 & 5 & 6 & 7 & 8 & & \\
\hline \multirow[t]{7}{*}{ Treadmill } & 0 & 3.158 & 3.160 & 3.171 & 3.169 & 3.225 & 3.201 & 3.214 & 3.207 & 3.188 & 0.027 \\
\hline & 32 & 3.354 & 3.334 & 3.370 & 3.397 & 3.256 & 3.449 & 3.383 & 3.351 & 3.362 & 0.055 \\
\hline & 62 & 3.592 & 3.580 & 3.602 & 3.580 & 3.422 & 3.689 & 3.661 & 3.557 & 3.585 & 0.080 \\
\hline & 86 & 3.778 & 3.806 & 3.784 & 3.744 & 3.586 & 3.895 & 3.851 & 3.707 & 3.769 & 0.094 \\
\hline & 110 & 3.929 & 3.973 & 3.965 & 3.931 & 3.798 & 4.059 & 4.058 & 3.883 & 3.950 & 0.087 \\
\hline & $r$ & 1.00 & 1.00 & 1.00 & 1.00 & 0.96 & 1.00 & 1.00 & 1.00 & 1.00 & 0.013 \\
\hline & Slope & 139 & 130 & 137 & 146 & 175 & 127 & 127 & 160 & 142 & 17.12 \\
\hline \multirow[t]{7}{*}{ Level ground } & 0 & 3.163 & 3.149 & 3.167 & 3.165 & 3.185 & 3.241 & 3.170 & 3.197 & 3.179 & 0.029 \\
\hline & 32 & 3.250 & 3.396 & 3.406 & 3.421 & 3.505 & 3.457 & 3.456 & 3.387 & 3.410 & 0.075 \\
\hline & 62 & 3.475 & 3.605 & 3.608 & 3.600 & 3.643 & 3.696 & 3.661 & 3.607 & 3.612 & 0.065 \\
\hline & 86 & 3.639 & 3.819 & 3.834 & 3.836 & 3.762 & 3.951 & 3.822 & 3.799 & 3.808 & 0.087 \\
\hline & 110 & 3.795 & 3.973 & 3.990 & 4.006 & 3.797 & 4.131 & 4.083 & 3.963 & 3.967 & 0.120 \\
\hline & $r$ & 0.99 & 1.00 & 1.00 & 1.00 & 0.96 & 1.00 & 1.00 & 1.00 & 1.00 & 0.012 \\
\hline & Slope & 163 & 132 & 132 & 130 & 169 & 120 & 124 & 141 & 139 & 17.80 \\
\hline
\end{tabular}

TU can detect the effect of inclination on the metabolic cost of walking, we measured Tracmor output and energy expenditure in subjects walking on a treadmill at varying inclination. Our eight weight-stable, rested subjects were four women and four men with a mean age of $33 \pm 9 \mathrm{yr}$, mean weight of $77 \pm 21 \mathrm{~kg}$, and mean BMI of $25 \pm 4$ $\mathrm{kg} / \mathrm{m}^{2}$. They were studied in the morning after having fasted from 22:00 $\mathrm{h}$ the night before. Energy expenditure and Tracmor output were measured concurrently in eight subjects while they were standing still and walking at 32, 62, and $86 \mathrm{~m} \cdot \mathrm{min}^{-1}$ at zero incline on the treadmill. The experiment was then repeated at inclinations of $17.5^{\circ}$ and $22.1^{\circ}$.

\section{Data Analysis}

All values are given as mean $\pm \mathrm{SD}$. To compare changes in energy expenditure or Tracmor output for a group of subjects, repeated-measures ANOVA was used with subsequent post hoc testing using two-sided paired $t$-tests. Statistical significance was defined as $P<0.05$.

\section{RESULTS}

\section{Experiment 1: TU Output Standing Motionless}

Published data (3) demonstrate that ambulating is associated with changes in Tracmor output of $>500 \mathrm{TU}$ above baseline. For subjects standing motionless, Tracmor output was stable and reproducible over the $14 \mathrm{~d}$ of study. For the 11 subjects, mean Tracmor output was $1452 \pm 20 \mathrm{TU}$ (range, 1425-1488 TU). For a given subject, the coefficient of variation for minute-to-minute variance was $<2 \%$.

\section{Experiment 2: Comparison of TU Output Walking on a Treadmill and Walking on Flat Ground}

As expected, Tracmor output increased with increasing velocity for walking both on the treadmill and on level ground. There were no significant differences for walking on the treadmill compared to level ground at any velocity, and the areas under the velocity/TU curves were similar
(Table 1). There were excellent linear correlations for TU versus $\mathrm{m} \cdot \mathrm{min}^{-1}$ for walking on the treadmill $(\mathrm{r}=1.00)$ and for walking on level ground $(\mathrm{r}=1.00)$. For a linear relationship where velocity $=\mathrm{a}+\mathrm{b}$. Tracmor output, for the treadmill, $\mathrm{a}=3.16$ and $\mathrm{b}=0.0070$; for walking on level ground, $a=3.18$ and $b=0.0072$. Similarly, for each individual studied, there were no significant differences for TU at each velocity or for the slope in comparisons of walking on the treadmill and on level ground. We noted that although Tracmor output was similar for each modality of walking for a given subject, there was variance $(\sim 10 \%)$ between individuals for each velocity studied.

\section{Experiment 3: Energy Expenditure and Tracmor Output for Walking on a Treadmill and Walking on Level Ground}

For the indirect calorimeter, repeated alcohol burns demonstrated recoveries of $\mathrm{O}_{2}$ and $\mathrm{CO}_{2}$ of $>98 \%$.

Tracmor output and energy expenditure increased with increasing velocity for both walking on the treadmill and on level ground (Table 2). Neither Tracmor output or energy expenditure was significantly different when in comparisons of walking on the treadmill and walking on level ground with increasing velocity. There were significant, positive correlations between the increment in energy expenditure above resting and weight for walking on the treadmill and on level ground.

When estimating the energy expenditure of walking in free-living subjects, we are most interested in how Tracmor output changes and whether this is representative of how energy expenditure changes above resting values. For the

TABLE 2. Tracmor output and energy expenditure while walking on the treadmill and level ground at variable velocity; data expressed as mean \pm SD.

\begin{tabular}{|c|c|c|c|c|}
\hline \multirow{2}{*}{$\begin{array}{r}\text { Velocity } \\
\left(\mathrm{m} \cdot \mathrm{min}^{-1}\right)\end{array}$} & \multicolumn{2}{|c|}{ Tracmor Output (TU.min ${ }^{-1}$ ) } & \multicolumn{2}{|c|}{ Energy Expenditure (kcal·h) } \\
\hline & Treadmill & Floor Walking & Treadmill & Floor Walking \\
\hline 0 & $1821 \pm 222$ & $1802 \pm 211$ & $67 \pm 13$ & $67 \pm 13$ \\
\hline 32 & $2720^{*} \pm 318$ & $2724^{\star} \pm 280$ & $139^{*} \pm 26$ & $141^{*} \pm 18$ \\
\hline 62 & $4708^{*} \dagger \pm 552$ & $4781^{\star} \dagger \pm 552$ & $183^{*} \dagger \pm 29$ & $196^{\star} \dagger \pm 22$ \\
\hline 86 & $7378^{*} \ddagger \pm 829$ & $7720^{\star} \ddagger \pm 890$ & $240^{*} \ddagger \pm 38$ & $267^{\star} \ddagger \pm 32$ \\
\hline
\end{tabular}

* Comparison with $0 \mathrm{~m} / \mathrm{min}$ (standing motionless), $P<0.001$.

† Comparison with $32 \mathrm{~m} / \mathrm{min}, P<0.001$.

$\ddagger$ Comparison with $62 \mathrm{~m} \cdot \mathrm{min}^{-1}, P<0.001$ 

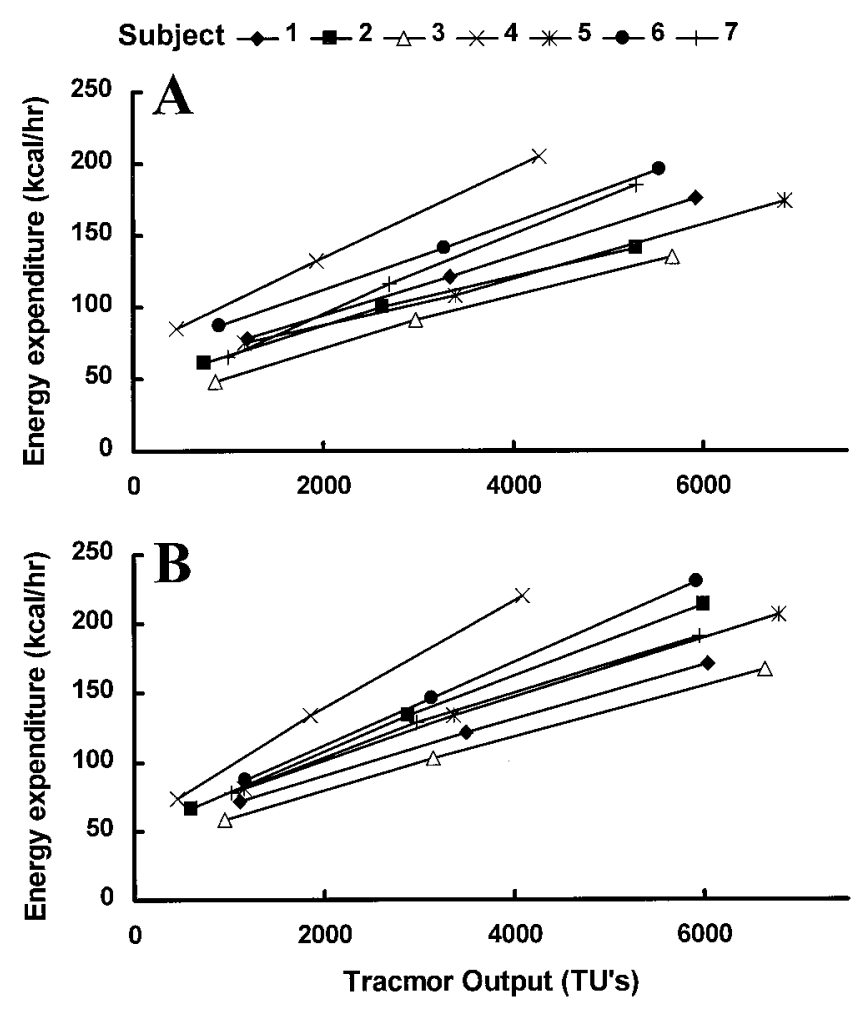

FIGURE 2-Changes in energy expenditure and Tracmor output above resting for seven healthy subjects walking on (A) a treadmill and (B) level ground at 32, 62, and $86 \mathrm{~m} \cdot \mathrm{min}^{-1}$. For each subject (1 through 7), three data points represent the effect on each variable at 32, 62, and $86 \mathrm{~m} \cdot \mathrm{min}^{-1}$.

group, the increment above resting in Tracmor output correlated with the increment above resting in energy expenditure for the treadmill $\left(\mathrm{r}^{2}=1.0\right.$, Tracmor $=$ energy expenditure $\left.\left(\mathrm{kcal} \cdot \mathrm{h}^{-1}\right) \cdot 46-2395\right)$ and for walking on level ground $\left(\mathrm{r}^{2}=1.0\right.$, Tracmor $=$ energy expenditure $\left(\mathrm{kcal} \cdot \mathrm{h}^{-1}\right)$ . $40-2047)$. Despite the fact the $r^{2}$ values for each subject were $>0.99$ for these relationships, the group regression equations did not predict for each subject the relationship between changes, above resting, in Tracmor output and energy expenditure either for walking on the treadmill or on level ground (Fig. 2). We also expressed energy expenditure relative to body weight. Again, a single regression equation did not predict the changes, above resting, in Tracmor output and energy expenditure either for walking on the treadmill or on level ground.

\section{Experiment 4: The Effect of Inclination on the Energy Expenditure of Walking and Tracmor Output}

We next determined whether the increments in the energy expenditure of walking that accompany increased inclination are matched by changes in the Tracmor output. By measuring energy expenditure and Tracmor output with increasing inclination, we determined that the Tracmor output was unchanged with increasing velocity, whereas the increases in the metabolic cost of walking increased significantly (Fig. 3). Tracmor output failed to mirror the in-
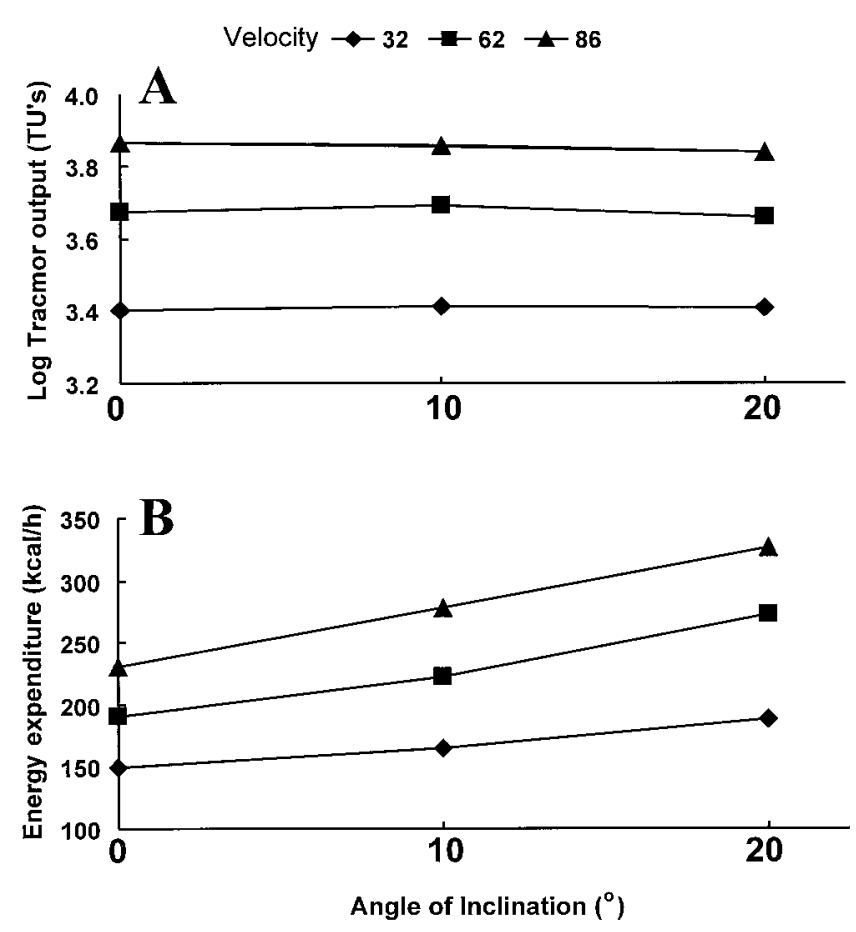

FIGURE 3-Inclination versus (A) Tracmor output and (B) energy expenditure for eight healthy subjects walking at 32, 62, and 86 $\mathbf{m} \cdot \mathbf{m i n}^{-1}$ on a treadmill.

creased metabolic cost of walking that occurs with increasing inclination.

\section{DISCUSSION}

The Tracmor triaxial accelerometer unit is one of the most widely and carefully validated portable devices for measuring human motion. Because walking is an important component of nonexercise activity thermogenesis, we felt it important to critically evaluate this instrument for walking.

Several types of instruments are available to measure walking in free-living subjects. Pedometers typically detect the displacement of physical objects with each stride. Pedometers tend to lack sensitivity because they do not quantify stride length or total body displacement. Accelerometers detect body displacement electronically with varying degrees of sensitivity: uniaxial accelerometers in one axis and triaxial in three axes. Portable uniaxial accelerometer units, such as the Caltrac accelerometer, have been widely used to detect walking (8). Careful evaluation demonstrates that these instruments are not sufficiently sensitive to quantify walking in free-living individuals, but rather they are more valuable for comparing activity levels between groups of subjects $(1,9,12,15)$. Greater precision for detection of walking has been obtained with triaxial accelerometers. Of these, the TU has been most widely validated $(2-5,13,16,17)$. This unit has several advantages besides being lightweight and portable $(2,3)$. First, the units have been validated against a motor-driven rotating arm where the test-to-test repeatability is $\sim 0.5 \%$, and when applied acceleration is plotted against accelerometer output, $r \approx 0.99$ (2). Second, conditions for optimum usage have been defined (e.g., site of 
attachment of accelerometer unit) (3). Third on a treadmill, Tracmor output has been demonstrated to correlate well with energy expenditure $(r=0.95)(5)$. Finally, with respect to detecting total body motion, Tracmor output correlates well with total daily energy expenditure (measured using doubly labeled water) divided by basal metabolic rate in free-living subjects $(\mathrm{r}=0.73 ; P<0.001)(4,16)$. We used the exact instruments in the above citations for our studies.

The results from these experiments allow us to define the utility of the Tracmor system for quantifying the amount and energy cost of walking. The TU are reproducible and stable over time. For a given subject, as velocity increases, Tracmor output increases in a log-linear and reproducible manner. However, a single regression equation does not predict this relationship for all subjects. Rather, separate regression equations are necessary for each subject, to reliably convert TU to velocity.

It was reassuring that Tracmor output was similar irrespective of whether a subjects walked on level ground or on a treadmill. This result was somewhat surprising to us because the biomechanics of the two modalities of walking are inherently different $(11,14)$, and experiments performed on subjects who are running on a track compared with a treadmill show differences in accelerometer output (15). Our result may reflect that the majority of work performed by the body when walking occurs with vertical displacement, which is consistent with the positive relationship between the metabolic cost of walking and weight (7).

\section{REFERENCES}

1. Bassett, D. R., Jr., B. E. Ainsworth, A. M. Swartz, S. J. Strath, W. L. O'Brien, and G. A. KING. Validity of four motion sensors in measuring moderate intensity physical activity. Med. Sci. Sports Exerc. 32(Suppl.):S471-S480, 2000.

2. Bouten, C. V., K. T. Koekroek, M. Verduin, R. Kodde, and J. D. JANSSEN. A triaxial accelerometer and portable data processing unit for the assessment of daily physical activity. IEEE Trans. Biomed. Engl. 44:136-147, 1997.

3. Bouten, C. V., A. A. Sauren, M. Verduin, and J. D. Janssen. Effects of placement and orientation of body-fixed accelerometers on the assessment of energy expenditure during walking. Med. Biol. Engl. Comput. 35:50-56, 1997.

4. Bouten, C. V., W. P. Verboeket-van de Venne, K. R. WesterTERP, M. Verduin, and J. D. JANSSEN. Daily physical activity assessment: comparison between movement registration and doubly labeled water. J. Appl. Physiol. 81:1019-1026, 1996.

5. Bouten, C. V., K. R. Westerterp, M. Verduin, and J. D. Janssen. Assessment of energy expenditure for physical activity using a triaxial accelerometer. Med. Sci. Sports Exerc. 26:1516-1523, 1994.

6. Bouten, C. V. C. Assessment of daily physical activity by registration of body movement. Doctoral dissertation, Einhoven University of Technology, Einhoven, the Netherlands, September, 1995.

7. Goldberg, G. R., A. M. Prentice, H. L. Davies, and P. R. MurGATROYD. Residual effect of graded levels of exercise on metabolic rate. Eur. J. Clin. Nutr. 44:99-105, 1990.

8. Haymes, E. M., and W. C. Byrnes. Walking and running energy expenditure estimated by Caltrac and indirect calorimetry. Med. Sci. Sports Exerc. 25:1365-1369, 1993.

9. Johnson, R. K., J. Russ, and M. I. Goran. Physical activity related energy expenditure in children by doubly labeled water as com-
These findings might guide the application of the TU for predicting the metabolic cost of walking in free-living subjects. The data suggest that the units can be attached to subjects over several days without instrument "drift"; they would be less useful if Tracmor output in the resting state changed with time and/or battery replacement. To convert Tracmor output to energy expenditure, a separate regression equation should be derived for each subject, which can be reliably obtained using a treadmill and metabolic cart similar to our own. The TU is not perfect for predicting the energy cost of walking because they fail to detect the increased energetic cost of walking on an incline. However, it should be noted that most walking is performed on level ground and that the inclinations we tested represent steeper ascents than would be encountered in most workday environments. Nevertheless, it seems unlikely that Tracmor output would match changes in energy expenditure with lesser inclines. These data will lead us to explore how well triaxial accelerometer systems detect changes in level terrain or activities such as stair climbing.

In conclusion, the Tracmor triaxial accelerometer is a useful tool for assessing the energetic cost of walking as long as separate regression equations are derived for each subject to convert Tracmor output to energy expenditure.

These studies were funded by the Mayo Foundation and by National Institutes of Health grants RR00585 and DK56650.

Address for correspondence: James A. Levine, M.D., Endocrine Research Unit, 5-194 Joseph, Mayo Clinic, 200 First St. SW, Rochester, MN 55905; E-mail: levine.james@mayo.edu.

pared with the Caltrac accelerometer. Int. J. Obes. Relat. Metab. Disord. 22:1046-1052, 1998.

10. Levine, J. A., N. L. Eberhardt, and M. D. Jensen. Role of nonexercise activity thermogenesis in resistance to fat gain in humans. Science 283:212-214, 1999.

11. Nigg, B. M., R. W. De Boer, and V. Fisher. A kinematic comparison of overground and treadmill running. Med. Sci. Sports Exerc. 27:98-105, 1995.

12. Pambianco, G., R. R. Wing, and R. Robertson. Accuracy and reliability of the Caltrac accelerometer for estimating energy expenditure. Med. Sci. Sports Exerc. 22:858-862, 1990.

13. Pannemans, D. L., C. V. Bouten, and K. R. Westerterp. $24 \mathrm{~h}$ energy expenditure during a standardized activity protocol in young and elderly men. Eur. J. Clin. Nutr. 49:49-56, 1995.

14. Stolze, H., J. P. Kuntz-Buschbeck, C. Mondwurf, et al. Gait analysis during treadmill and overground locomotion in children and adults. Electroencephalogr. Clin. Neurophysiol. 105:490497, 1997.

15. Swan, P. D., W. C. Byrnes, and E. M. Haymes. Energy expenditure estimates of the Caltrac accelerometer for running, race walking, and stepping. Br. J. Sports Med. 31:235-239, 1997.

16. Westerterp, K. R., and C. V. Bouten. Physical activity assessment: comparison between movement registration and doubly labeled water method. Z. Ernahrungswiss. 36:263-267, 1997.

17. Westerterp, K. R., W. P. Verboeket-van de Venne, C. V. Bouten, C. de Graaf, K. H. van het Hof, and J. A. Weststrate. Energy expenditure and physical activity in subjects consuming full or reduced fat products as part of their normal diet. Br. J. Nutr. 76:785-795, 1996. 